University of Nebraska - Lincoln

DigitalCommons@University of Nebraska - Lincoln

Faculty Publications from the Harold W. Manter Laboratory of Parasitology

$11-1964$

Studies on the Helminth Fauna of Alaska. XLI. Observations on

Cestodes of the Genus Diplogonoporus Lönnberg, 1892 (Diphyllobothriidae)

Robert L. Rausch

Arctic Health Research Center, rausch@u.washington.edu

Follow this and additional works at: https://digitalcommons.unl.edu/parasitologyfacpubs

Part of the Parasitology Commons

Rausch, Robert L., "Studies on the Helminth Fauna of Alaska. XLI. Observations on Cestodes of the Genus Diplogonoporus Lönnberg, 1892 (Diphyllobothriidae)" (1964). Faculty Publications from the Harold W. Manter Laboratory of Parasitology. 527.

https://digitalcommons.unl.edu/parasitologyfacpubs/527

This Article is brought to you for free and open access by the Parasitology, Harold W. Manter Laboratory of at DigitalCommons@University of Nebraska - Lincoln. It has been accepted for inclusion in Faculty Publications from the Harold W. Manter Laboratory of Parasitology by an authorized administrator of DigitalCommons@University of Nebraska - Lincoln. 


\title{
STUDIES ON THE HELMINTH FAUNA OF ALASKA XLI. OBSERVATIONS ON CESTODES OF THE GENUS DIPLOGONOPORUS LÖNNBERG, 1892 (DIPHYLLOBOTHRIIDAE)
}

\author{
Robert L. Rausch \\ Arctic Health Research Center, U.S. Department of Health, Education, and Welfare, \\ Anchorage, Alaska \\ Received May 25, 1964
}

\begin{abstract}
The study of a collection of cestodes assigned to the genus Diplogonoporus Lönnberg, 1892 disclosed but two species, D. balaenopterae Lönnberg, 1892, and D. tetrapterus (von Siebold, 1848) (provis.). These cestodes occur characteristically in marine mammals but occasionally are found in terrestrial hosts; $D$. balaenopterae is recorded for the first time from the domestic dog, and it is concluded that $D$. grandis (Blanchard, 1894), from man, is conspecific with $D$. balaenopterae. The latter species is recorded for the first time from the humpback whale, Megaptera novaeangliae (Borowski). The relatively small D. tetrapterus, a common parasite of the Steller sea lion, Eumetopias jubata (Schreber), is reported for the first time from the sea otter, Enhydra lutris I.innaeus, and from the domestic mink, Mustela vison Schreber. Descriptions of representative specimens are presented, and the taxonomic status of other species assigned to Diplogonoporus is discussed. Although the diplogonadic organization of these cestodes is somewhat variable, it is nevertheless constant and serves to characterize the genus Diplogonoporus. The process of asexual reproduction by means of transverse subdivision of primary segments is described. 'This ability and the diplogonadic structure of these cestodes are considered to be adaptations that increase the production of eggs and thereby the probability of reproductive success in the marine habitat.
\end{abstract}

\section{Introduction}

The species of Diplogonoporus Lönnberg, 1892 compose a distinctive assemblage of diphyllobothriid cestodes in having typically two sets of reproductive organs in each segment. In other morphological characteristics they are similar to cestodes of the genus Diphyllobothrium Cobbold, 1858. Published records indicate that Diplogonoports species occur usually in cetaceans and pinnipeds, although mammals belonging to other groups occasionally have been found to be infected. One species has been considered to be exclusively a parasite of man.

In July, 1956, three large cestodes referable to this genus were given to me for determination by Karl W. Kenyon, of the United States Fish and Wildlife Service, Seattle, who had found them in the intestine of a sea otter, Enhydra lutris Linnaeus, captured in waters around Amchitka Island, in the Aleutian Islands. These cestodes did not apparently resemble any of the known species of Diplogonoporus, and since the contracted condition of the strobilae caused some of the diagnostic details to be obscured, further study was postponed in the hope that additional material could be secured. A fourth specimen, also contracted, was provided by $\mathrm{Mr}$. Kenyon in 1957, and not until 1962 were several relaxed strobilae obtained from a sea otter found dead of natural causes at Montague Island. The purpose of this paper is to present the results of the study of these and other cestodes assignable to the genus Diplogonoporus. 


\section{Materials and Methods}

The material studied was collected from 13 mammals representing seven species. Most specimens had been fixed in 10\% formalin; in some cases, when the cestodes had been preserved immediately after removal from the host, the strobilae were strongly contracted. Complete specimens or selected portions of the larger strobilae were stained in Semichon's acetic carmine or in Ehrlich's acid hematoxylin and mounted entire. One lot of material (United States National Museum (U.S.N.M.) No. 18783) consisted of prepared slides bearing short series of segments. Certain portions of strobilae were chosen to be embedded by the paraffin method, serially sectioned both transversely and sagittally at 7 to $15 \mu$, and stained with hematoxylin-eosin. Dissections made under low magnification on stained segments that had been cleared in terpineol were also found to be of value.

\section{Descriptions of Species}

After a comparative analysis of the data compiled on the 13 lots of material, it was concluded that only two species of Diplogonoporus were represented; these were $D$. balaenopterae Lönnberg, 1892, and a species here provisionally designated $D$. tetrapterus (von Siebold, 1848). Of those cestodes that are usually assigned to the genus Diplogonoporus, there has long been controversy concerning the systematic status, and it seems appropriate, therefore, to include here detailed descriptions of representative specimens from the various species of hosts. Any reference made below to the number of sets of genital organs present in individual segments does not include the testes and vitelline follicles.

\section{Diplogonoporus balaenopterae LönNBerG, 1892}

\section{Material Studied}

One cestode from domestic dog, Anchorage, Alaska, June 12, 1958 (new host record); two cestodes from humpback whale, Megaptera novaeangliae (Borowski), off San Francisco, California, September 21, 1961 (new host record); two slides (U.S.N.M. No. 18783) containing portions of a strobila from an unidentified whale, from waters off Seattle, Washington, March 15, 1918.

Cestode from Dog (Figs. 1 and 2)

Diagnosis

Total length $2765 \mathrm{~mm}$ (well relaxed strobila), with 2648 segments; maximum width, attained in posterior portion of strobila, $15 \mathrm{~mm}$. Maximum thickness of segments at level of genital pore, $1.0 \mathrm{~mm}$. All segments wider than long; length/width ratio of about $1: 10$ in earlier segments, containing mature eggs, and about $1: 8$ in segments near posterior end of strobila. Strobilar margins slightly serrate, parallel. Scolex relatively small, measuring $2.5 \mathrm{~mm}$ long by about $1.3 \mathrm{~mm}$ wide in lateral view, and oval in shape, with deep bothria running full length. Neck absent. Transverse subdivision of earlier segments regular and consistént. Genital Anlagen visible about $120 \mathrm{~mm}$ from scolex.

Segments usually diplogonadic; additional sets of reproductive organs, either rudimentary or functional, sometimes present. Openings of genital ducts ventral, surrounded by comparatively large, elevated area. Genital 

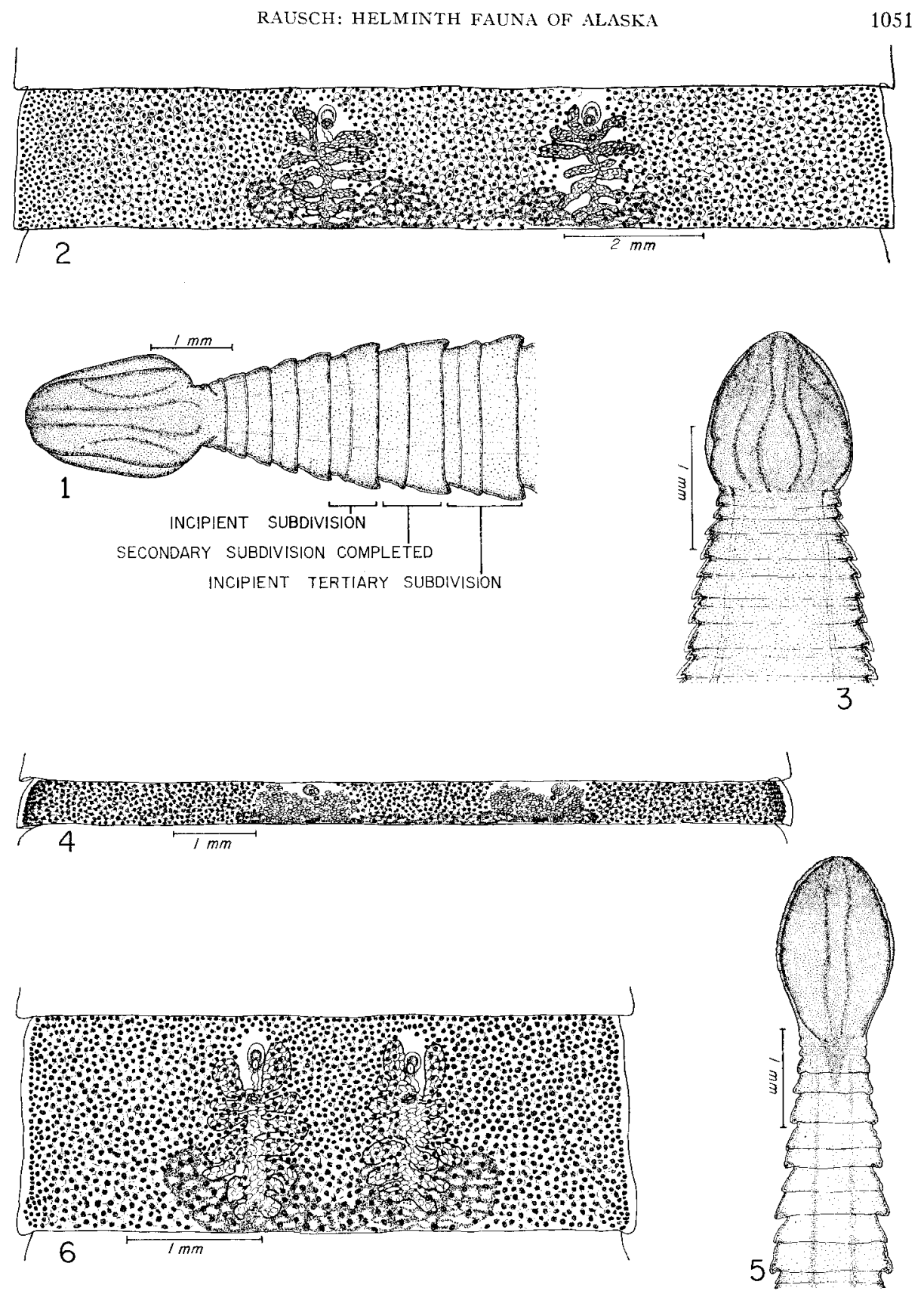

FIG. 1. Scolex of D. balaenoplerae from a dog, illustrating subdivision of early segments.

FIG. 2. Segment of D. balaenopterae from a dog. Ventral view.

FIG. 3. Scolex of $D$. tetrapterus from sea otter. Contracted strobila.

FIG. 4. Segment of D. tetrapterus from sea otter. Moderately contracted strobila, ventral view.

FIG. 5. Scolex of D. tetrapterus from sea otter. Relaxed strobila.

FIG. 6. Segment of $D$. tetrapterus from sea otter. Relaxed strobila, ventral view. 
pores situated near anterior margin of segment, usually near edge of velum of preceding segment, and separated by distance equal to about one-third of segmental width. Cirrus sac and vagina open in common genital atrium; integument of latter papillose. Uterine pore separate, about $200 \mu$ posterior to common genital pore. Slit-like fold in cuticle sometimes present, continuing from genital pore posteriad and encompassing uterine pore.

Cirrus sac thin-walled, piriform, about 430 by $215 \mu$, extending slightly anteriad from opening in anterior floor of genital atrium. Ovoid to spherical Propulsionblase thick-walled, measuring about 180 by $110 \mu$, and extending slightly posteriad from proximal end of cirrus sac. Vas deferens enters proximal end of Propulsionblase after passing anteriad in dorsal part of segment. Subspherical testes, measuring 150 to $180 \mu$ in greatest diameter, disposed in layer occupying central portion of parenchyma excepting areas surrounding uteri and genital pores; latter separate testes into three discrete fields, each of lateral fields containing about 300 testes, with somewhat fewer in middle field, resulting in total of about 1000 testes per segment. Transverse sections at level of genital pores reveal 30 to 32 testes, arranged in single layer, lateral to each genital pore, and up to 45 , arranged two to three deep, between uterine masses.

Thin-walled vagina directed anteriad from ovary across ventral surface of uterine coils, turning ventrad at about level of genital pore, paralleling cirrus sac and opening in posterior floor of genital atrium. Each ovary reticulate, situated ventrally at posterior margin of segment, and comprised of two lobes connected posteriorly by narrow isthmus and extending anteriad along both sides of uterine coils; medial ovarian lobes usually confluent by means of thin strand of tissue extending across posterior portion of central field of each segment. Vitelline follicles abundant, 35 to $70 \mu$ in greatest diameter, disposed throughout cortical zone excepting areas around uteri and genital pores ventrally, and corresponding areas dorsally, overlapping ends of uterine loops and sometimes confluent both dorsally and ventrally across anterior margin of segment. Vitelline ducts converge near ovary, forming two main ducts for each set of reproductive organs. Posterior portion of uterus much coiled; anterior portion, containing fully developed eggs, forms on each side of midline three or four loops, anteriormost of which usually extending beyond genital pore, sometimes nearly reaching anterior margin of segment. Operculate eggs measure 63 to $74 \mu$ by 39 to $52 \mu$ (av. for $100: 68$ by $43 \mu$ ).

A slide containing a portion of this strobila has been deposited in the Helminthological Collection of the United States National Museum, No. 60359 .

\section{Cestodes from Humpback Whale}

The two cestodes from this host had been wrapped on stiff cardboard before fixation and were consequently somewhat stretched. Except for its greater size, the larger strobila differed only in minor morphological details from that obtained from the $\mathrm{dog}$.

\section{Diagnosis}

Length $5800 \mathrm{~mm}$ (scolex lacking); maximum width, attained near posterior end of strobila, $20 \mathrm{~mm}$. Segments usually diplogonadic, with genital pores 
near anterior margin of segment. Genital Anlagen visible in segments 330 $\mathrm{mm}$ from anterior extremity of strobila. Cirrus sac up to $600 \mu$ long by 250 $\mu$ wide. Propulsionblase situated slightly posterior to proximal end of cirrus sac. Testes in three discrete fields. In transverse sections at level of genital pores, up to 40 testes, arranged in single row, visible lateral to each uterine mass; more than 30 testes visible in middle field. Vitellaria, absent from areas surrounding uteri and genital pores ventrally, and from corresponding areas dorsally, more widely distributed dorsally, with lateral fields encroaching farther mediad and middle field more extensive; not overlapping ends of uterine loops, and only rarely confluent dorsally across anterior margin of segment. Anterior portion of uterus, containing fully developed eggs, forms five to eight loops on each side of midline. Eggs average 66.4 by $45.4 \mu$.

The second specimen from the humpback whale was poorly developed, having a length in excess of $7420 \mathrm{~mm}$ but attaining a maximum width of only $10 \mathrm{~mm}$. The scolex and the first part of the strobila were missing, and the genital Anlagen were already well defined in the anteriormost segment present. The uteri appeared to be normally developed in the older segments, but only their posterior loops contained eggs, all of which were immature. Otherwise, this cestode resembled the larger specimen in morphological details.

\section{Cestode from Unidentified Whale}

The prepared slides from the collection of the U.S. National Museum (No. 18783) contained segments from a strobila taken from an unidentified whale. The condition of the material permitted only limited observations on the anatomy. It is possible that a portion of this strobila was studied earlier by Baer (1932, p. 214).

\section{Diagnosis}

Segments diplogonadic, with length/width ratio of about 1:15. Genital pores situated near anterior margin of segment. Testes separated into three discrete fields. Vitellaria, absent from areas surrounding uteri and genital pores ventrally, and from corresponding areas dorsally, more widely distributed dorsally, with lateral fields encroaching farther mediad, overlapping ends of uterine loops but not confluent across anterior or posterior margins of segment. Anterior portion of uterus, containing fully developed eggs, apparently forms on each side of midline up to eight loops, the anteriormost frequently extending anteriad beyond genital pores. Fggs measure from 62 to $66 \mu$ by 37 to $47 \mu$ (av. for 100: 63.8 by $43.6 \mu$ ).

\section{Comparative Notes}

The anatomical differences observed in the cestodes studied, as well as the differences between these cestodes and the published descriptions of $D$. balaenopterae, are minor in nature, involving mainly a relationship to the size and state of contraction of the strobila. They did not exceed the expected limits of normal intraspecific variation.

Superficially, longitudinal grooves were not well developed in the cestodes studied, but, as remarked by Baer (1932), their presence depends on the state of contraction of the strobila. As many as 10 such grooves, of which 2 corresponded to the rows of genital openings, were observed by Lönnberg (1892), whose material was strongly contracted (Lönnberg 1892, Fig. 3). Two grooves 
following the genital openings were noted also by Markowski (1955) in a comparatively relaxed strobila. The undulations in the anterior portion of the strobila described by Markowski (Plate XXI, Figs. 5 and 6) were evidently caused by the method of fixation.

Variation in the distribution of the vitellaria is often observed in diphyllobothriid cestodes, in which rather striking differences may be observed from strobila to strobila of the same species, or even from segment to segment in a single strobila. In the larger cestode from the humpback whale, the middle field of some segments lacked vitelline follicles ventrally, while that of others possessed few.

Because of their large numbers and position, the testes are difficult to count accurately. Moreover, there is considerable variation in the number of testes per segment. Yamaguti (1942) reported a range of 600 to 1300 testes per segment, depending on whether secondary subdivision of the segment had taken place. He pointed out that there were always more than the 200 to 300 per segment reported by Baer (1932). However, Baer may have intended his count to apply to each of the three fields, rather than to the entire segment. Deliamure (1955) reported an approximate number of 1700 to 2000 testes per segment. Since the disposition of the testes is modified by changes in the degree of strobilar contraction, different numbers will be visible in different transverse sections. Markowski's (1955) observations suggest that irregularity in the number of testes may exist from field to field in a single segment.

The size of the cirrus sac is subject to variation, the following dimensions having been reported for $D$. balaenopterae: 370 by $280 \mu$ (Baer 1932); 300 to $400 \mu$ in diameter (Yamaguti 1942); 345 by $300 \mu$ (Markowski 1955); 528 by $582 \mu$ (Deliamure 1955). The dimensions of the cirrus sac reported in the present paper for the cestode from the humpback whale exceed any previously recorded for $D$. balaenopterae. The form of the cirrus sac is modified by changes in degree of strobilar contraction. The sac becomes much lengthened in relation to its diameter in strongly contracted cestodes (see Lönnberg 1892. Fig. 9), extending farther dorsad than is the case in relaxed strobilae.

The number of loops in the anterior portion of the uterus may depend on the age and reproductive state of the strobila. Differences are scen also in the quantity of eggs present; in some specimens the uterine loops become so distended with eggs as to be indistinguishable, while in others they remain quite distinct. The size of the eggs in the material studied here is consistent with previously reported dimensions: 63 by 48 to $50 \mu$ (Kurimoto 1900); 62 to 72 by $53 \mu$ (Baer 1932); 54 to 71 by 43 to $48 \mu$ (Yamaguti 1942); 66 by $48 \mu$ (Markowski 1955); 57 to 61 by 38 to $42 \mu$ (Deliamure 1955).

Status of Diplogonoporus grandis (Blanchard, 1894)

When the diplogonadic cestode was reported from man by Ijima and Kurimoto (1894), it was considered to be possibly the same as one of the species previously described from seals, but its identity was not established. Evidently unaware of the earlier paper by Lönnberg (1892), Blanchard (1894) designated this cestode Krabbea grandis. Kurimoto (1900), recognizing its morphological similarity to $D$. balaenopterae but convinced of its specific distinction, placed it in the genus Diplogonoporus. 
In his revision of the bothriocephalids, Lühe $(1899$, p. 50$)$ stated that $D$. grandis "... stimmt nach den Angaben von Ijima u. Kurimoto und nach eigener Untersuchung eines mir von Kurimoto überlassenen Bruchstückes des Originalexemplars anatomisch vollkommen mit Diplogonoporus balaenopterae Lönnbg. überein. Der wichtigste Unterschied zwischen beiden Arten scheint zu sein, dass bei Dipl. grandis die Dotterstöcke an der Ventralfäche des Mittelfeldes ganz ausserordentlich spärlich sind, was bei Dipl. balaenopterae nach Lönnberg's Angaben nicht der Fall zu sein scheint." Baer (1932, p. 216) noted in transverse sections of $D$. balaenopterae that ". . les follucules vitellins soient plus abondants à la face dorsale du segment qu'à la face ventrale." Variation in the abundance of vitelline follicles in material considered in the present study has already been described. Clearly there exist no significant differences in the distribution of the vitellaria between the cestodes from man and those from whales. Neither does the small number of uterine loops (two on each side of midline) appear to have significance, for such loops are known to be variable in number in $D$. balaenopterae as in diphyllobothriid cestodes generally; moreover, greater numbers have subsequently been observed in specimens of Diplogonoporus from man by Morishita (1962), whose studies of a quantity of material of human origin disclosed no characters which distinguished his specimens from $D$. balaenopterae.

Host occurrence has no value as a means of distinguishing these cestodes, since, in the case of the diphyllobothriid species, the acquisition of the parasite by the final host depends not so much on immunophysiological factors as on the ecological conditions existing within the environment of the host. Accordingly, $D$. balaenopterae might be expected to develop in mammals of any species that find opportunity for ingestion of the plerocercoid larva, for example, in man or dog in regions where certain fishes of marine origin are regularly utilized. Recognition of $D$. grandis as a distinct species in man seems clearly to involve $D$. balaenopterae in an unusual host. $D$. grandis also has been reported (Barabash-Nikiforov 1947) from a sea otter; in this case, however, it is probable that the species was $D$. tetrapterus, which is discussed below.

It is concluded that $D$. grandis cannot be distinguished from $D$. balaenopterae by morphological characteristics or other criteria. Consequently, $D$. grandis (Blanchard, 1894) is considered a synonym of $D$. balaenopterae Lönnberg, 1892.

\section{Diplogonoporus tetrapterus (von Siebold, 1848) (PRovis.) \\ Material Studied}

Three cestodes from sea otter, Enhydra lutris, Amchitka Island, July 1956 (new host record); 1 from sea otter, Amchitka Island, December 9, 1957; numerous cestodes from sea otter, Montague Island, Prince William Sound, April 23, 1962; fragment of 1 (U.S.N.M. No. 44163) from domestic mink, Mustela vison Schreber, Petersburg, Alaska, January 2, 1940 (new host record); 5 cestodes from fur seal, Callorhinus ursinus (Linnaeus), Valdez, Alaska, January 1961; from Steller sea lion, Eumetopias jubata (Schreber): 5 cestodes, St. Lawrence Island, August 30, 1950; 3, St. Lawrence Island, October 23, 1959; 69, Montague Island, 1956; 6, Montague Island, June 1958; and two lots of 10 and 21 cestodes, Montague Island, July 11, 1960. 
Cestodes from Sea Otter, Contracted State (Figs. 3 and 4)

The first diagnosis is based on four cestodes from sea otters captured at Amchitka Island. Three specimens were strongly contracted, the fourth moderately so.

\section{Diagnosis}

Total length of moderately contracted strobila $1840 \mathrm{~mm}$; length of longest fragment of strongly contracted strobila, $1170 \mathrm{~mm}$. Maximum width, attained in posterior portion, 7 to $10 \mathrm{~mm}$. All segments wider than long and as much as $2.5 \mathrm{~mm}$ thick; segments containing fully developed eggs with length/ width ratio of $1: 25$ to $13: 0$ (strongly contracted), or $1: 12$ (moderately contracted). Strobilar margins parallel, smooth. Scolex cordate, relatively small, measuring about 1.1 to $1.2 \mathrm{~mm}$ wide by 1.2 to $1.7 \mathrm{~mm}$ long in lateral view; bothria deep, extending full length of scolex. Neck absent. Subdivision of segments regular, producing up to nine secondary segments from each primary segment. Segments very numerous, with about 30 per $\mathrm{cm}$ in gravid portion of strongly contracted strobilae, or about 16 per $\mathrm{cm}$ in moderately contracted strobilae. Two longitudinal, parallel grooves present on both ventral and dorsal surfaces of strobila, and corresponding to areas free of vitelline follicles. Secondary grooves, also longitudinal, sometimes present. Longitudinal muscles strongly developed, forming thick layer between vitelline follicles and transverse muscle layer.

Segments usually diplogonadic, often with additional sets of reproductive organs, or rudiments thereof, situated between normally developed structures. Openings of genital ducts ventral, covered by velum of preceding segment and scparated by distance of about one-third of segment width. Cirrus sac and vagina open in common genital atrium; latter with rounded protuberances on surface. Uterine pore opens separately, just posterior to genital pore.

Thin-walled cirrus sac, much elongated in contracted segments, measures about 360 by $100 \mu$ and extends dorsad through more than one-half of segment. Propulsionblase, elongate, situated at proximal end of cirrus sac, receives entry of vas deferens at proximal end. Testes, much distorted in contracted segments, disposed in sheet in central portion of parenchyma excepting areas occupied by uteri and genital pores, latter areas separating testes into three discrete fields. In transverse sections at level of genital pores, up to 40 testes are visible in single layer lateral to each genital pore; these are much compressed laterally, with dorsoventral dimension of about $200 \mu$. Testes between uterine masses fewer, arranged two to three deep.

Vagina ventral and superficial, opening in posterior floor of genital atrium. Each ovary, situated ventrally at pasterior margin of segment, comprised of two lobes connected posteriorly by narrow isthmus; ovarian structure reticulate, with medial lobes of both confluent by means of tissue extending across posterior portion of central field of segment. Ovaries much compressed in contracted segments, appearing as narrow, transverse band. Vitellaria, abundant throughout cortical zone excepting small area surrounding genital pores and uteri ventrally, and corresponding dorsal areas, overlap greater part of uterine loops and usually confluent anteriorly and posteriorly across middle field of segment. Individual vitelline follicles measure about 15 to $35 \mu$ in greatest diameter. Anterior portion of uterus forms five to six loops on 
each side of midline; loops much compressed in contracted segments. Operculate eggs measure 66 to 70 by 37 to $42 \mu$ (av. 67.5 by $40 \mu$ ).

Slides bearing parts of one strobila and unmounted portions of another have been deposited in the Collections of the United States National Museum, Nos. 60360 and 60361 .

Cestodes from Sea Otter, Relaxed State (Figs. 5 and 6)

The intestine of a sea otter found dead on Montague Island contained numerous cestodes of the species described above. These cestodes had evidently relaxed after the death of the host; they were dead when collected, and some had begun to degenerate. No strobilac were obtained intact.

\section{Diagnosis}

Largest fragment $1262 \mathrm{~mm}$ long; maximum width of gravid segments 5.5 $\mathrm{mm}$. All segments wider than long, with length/width ratio of 1:5 to 1:10; longest segments had not undergone subdivision. Strobilar margins slightly serrate. Scolex relatively small, lanceolate, cordate, or nearly round in lateral view, and measuring up to $1.3 \mathrm{~mm}$ wide by $2 \mathrm{~mm}$ long. Segments numerous, six to nine per centimeter in gravid portion of strobilae. Subdivision of segments somewhat irregular. Superficial grooves on strobila weakly defined or not visible.

Segments usually diplogonadic; additional sets of reproductive organs sometimes present. Openings of genital ducts ventral, in anterior portion of segment just posterior to velum of preceding segment, and scparated by distance equal to about one-third of segment width. Cirrus sac thin-walled, piriform, measuring about 320 by $180 \mu$, and extending slightly anteriad from opening in anterior floor of genital atrium. Propulsionblase more or less ovoid, measuring about 140 by $110 \mu$, and situated slightly posterior to proximal end of cirrus sac. Subspherical testes, measuring 50 to $70 \mu$ in greatest diameter, disposed in sheet in central portion of parenchyma excepting areas occupied by uteri and genital pores; latter areas separate testes into three fields which may be confluent across anterior margin of segment. Total number of testes about 900-1000, with 230 to 300 in lateral fields and about 300 in middle field; subdivided segments have about one-half as many. In cross section at level of genital pores, 15 to 20 testes visible in single layer lateral to each genital pore; between uterine masses only 5 or 6 to be seen.

Each ovary situated ventrally at posterior margin of segment and comprised of two lobes; medial lobes in contact or confluent across posterior portion of central field. Vitellaria, abundant throughout cortical zone excepting areas surrounding genital pores and uteri ventrally, and corresponding dorsal areas, overlap greater part of uterine loops and are confluent across anterior and posterior portions of segments both dorsally and ventrally. Anterior portion of uterus forms on each side of midline four to five loops, anteriormost usually extending anteriad beyond genital pore, sometimes nearly reaching anterior margin of segment. Operculate eggs measure 63 to 70 by 39 to $50 \mu$ (av. for 100: 66 by $44 \mu$ ).

Cestodes from Sea Lion, Contracted State (Fig. 7)

Nearly all the cestodes from Steller sea lions were strongly contracted, ranging in length from immature individuals measuring as little as $17 \mathrm{~mm}$, to 

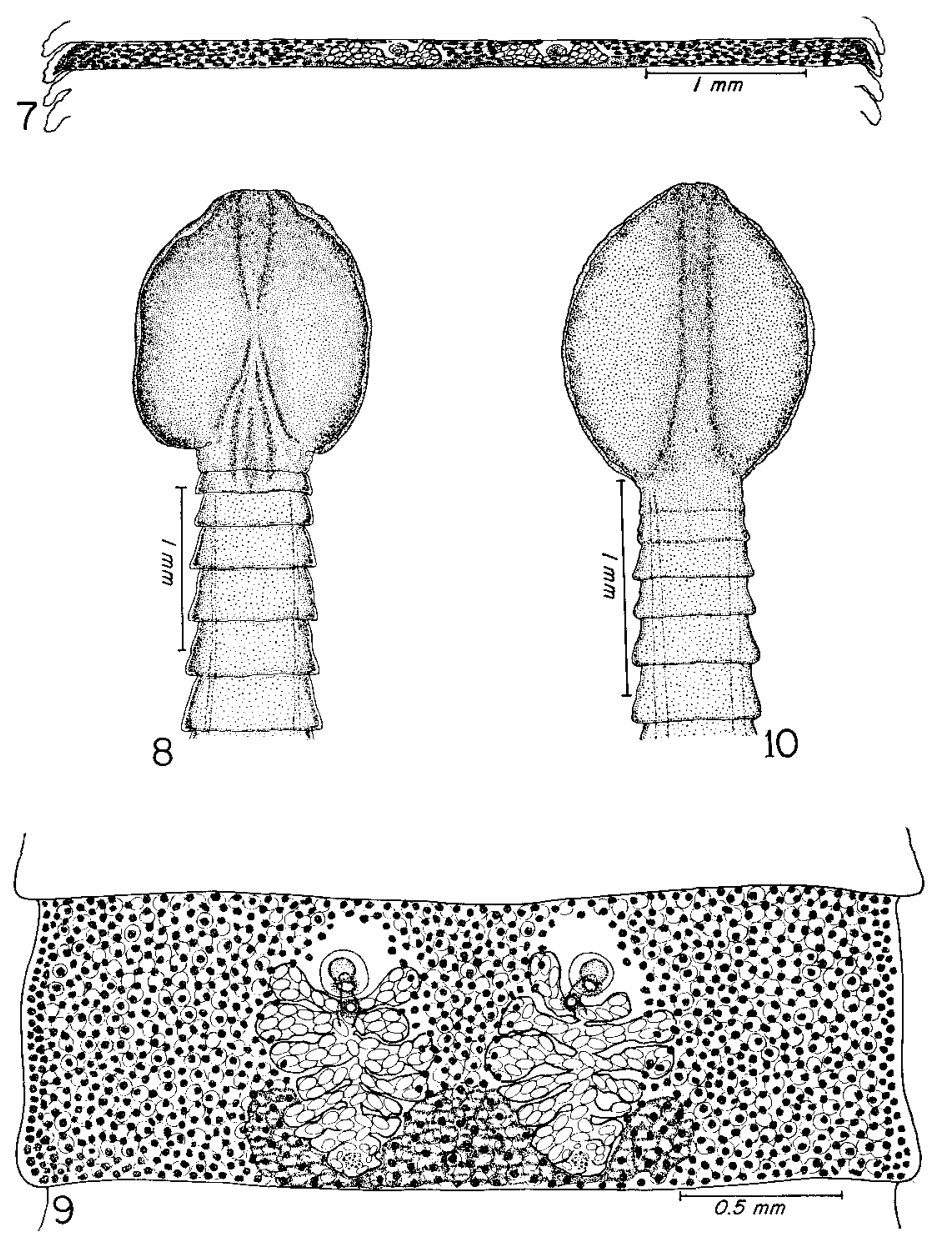

FIG. 7. Segment of $D$. tetrapterus from Steller sea lion. Contracted strobila, ventral view.

FIG. 8. Scolex of D. tetrapterus from Steller sea lion. Relaxed strobila.

FrG. 9. Segment of $D$. tetrapterus from Steller sea lion. Relaxed strobila, ventral view.

FIG. 10. Scolex of D. ?tetrapterus from fur seal.

$225 \mathrm{~mm}$ in the largest specimen. All of these were collected from sea lions captured at Montague Island.

\section{Diagnosis}

Length up to $225 \mathrm{~mm}$; maximum width, attained in posterior part of strobila, $5 \mathrm{~mm}$; thickness to about $1.2 \mathrm{~mm}$. All segments much wider than long, those containing eggs having length/width ratio of about $1: 10$ to $1: 16$. Strobilar margins parallel, smooth. Scolex lanceolate to cordate, 1.3 to $1.5 \mathrm{~mm}$ wide by as much as $2 \mathrm{~mm}$ long in lateral view. Neck absent. Subdivision of segments characteristic. Segments very numerous, with about 45 per $\mathrm{cm}$ in posterior portion of larger strobilae. On both ventral and dorsal surfaces, strobila exhibits two longitudinal grooves, which correspond in position to areas free of vitellire follicles. 
Segments typically diplogonadic, sometimes with additional sets of reproductive organs; monogonadic segments or series of monogonadic segments present in some strobilae. Openings of genital ducts ventral, situated near anterior margin of segment, and separated by distance equal to about onethird of segmental width. Genital Anlagen visible 30 to $45 \mathrm{~mm}$ posterior to scolex. Cirrus sac and vagina open in common genital atrium; surface of latter exhibits rounded protuberances. Uterine pore separate, opening just posterior to genital pore.

Cirrus sac much elongated, measuring up to $390 \mu$ long by about $100 \mu$ wide, and extending dorsad through more than one-third of thickness of segment. Propulsionblase likewise elongated, situated at proximal end of cirrus sac. Testes, measuring 40-50 $\mu$ in greatest diameter, disposed in sheet in central portion of parenchyma excepting areas occupied by genital pores and uteri; latter areas separate testes into three fields confluent across anterior margin of segment. Transverse sections at level of genital pores exhibit considerable number of distorted testes situated lateral to each of uterine masses; few present in middle field.

Each ovary situated ventrally at posterior margin of segment and comprised of two lobes, those medial confluent across central field in posterior portion of segment. Ovaries much compressed, forming transverse band across posterior part of segment. Abundant, dense vitellaria, distributed throughout cortical zone excepting area around genital pores and over uteri ventrally, with corresponding areas free of vitellaria dorsally, overlap uterine loops and are confluent across anterior margin of segment, both dorsally and ventrally. Anterior portion of uterus forms four to five loops on each side of midline; latter compressed and not extending anterior to genital pore. Operculate eggs measure 65 to 76 by 42 to $52 \mu$ (av. for 100 : 70 by $43.7 \mu$ ).

Cestodes from Sea Lion, Relaxed State (Figs. 8 and 9)

Relaxed strobilae were found in only two sea lions, one from St. Lawrence Island and one from Montague Island.

\section{Diagnosis}

Length (specimens with gravid segments) 186 to 574 mm; maximum width, attained in posterior portion of strobila, $4 \mathrm{~mm}$. All segments wider than long, gravid segments having length/width ratio of about $1: 4$ to $1: 8$, depending on extent of subdivision. Strobilar margins slightly serrate. Scolex cordate, measuring up to $2 \mathrm{~mm}$ wide by $2 \mathrm{~mm}$ long in lateral view. Bothria deep, extending full length of scolex. Neck absent or very short. Subdivision of segments irregular. Segments numerous; 699 discrete (fully divided) segments in strobila $500 \mathrm{~mm}$ long. Superficial grooves not visible.

Segments usually diplogonadic, sometimes with additional sets of reproductive organs; some strobilae with series of monogonadic segments. Openings of genital ducts ventral, situated near anterior margin of segment and usually separated by distance equal to about one-quarter to one-third of segmental width; latter distance may be variable, and in some cases is reduced to degree that loops of two uteri interdigitate. Genital Anlagen visible at end of about first one-fifth of strobilar length. Cirrus sac and vagina open in common genital atrium; latter lined on surface with rounded protuberances measuring about 
$20 \mu$ in diameter and $10 \mu$ high. Uterine pore situated 65 to $100 \mu$ posterior to genital pore.

Cirrus sac piriform, directed slightly anteriad, and measuring up to 320 by $143 \mu$. Propulsionblase ovoid to spherical, 110 to $120 \mu$ in greatest diameter, and situated slightly posterior at proximal end of cirrus sac. Testes 50 to 70 $\mu$ in greatest diameter, disposed in single layer in central part of parenchyma excepting areas occupicd by genital pores and uteri; latter areas separate testes into three fields of ten confluent across anterior part of segment. About 15 testes visible lateral to each of uterine masses in transverse sections at level of genital pores; few testes present in middle field. Total number of testes per segment ahout 700-900, with 230-300 in lateral fields and about 110-150 in middle. Fewer testes present in segments that have subdivided.

Ovaries, each consisting of two lobes, situated ventrally near posterior margin of segment; two medial lobes may be confluent. Abundant, dense vitellaria distributed throughout cortical zone excepting small area around genital pores and uteri ventrally, and small, corresponding areas dorsally, overlap uterine loops and may be confluent across anterior and posterior margins of segment both dorsally and ventrally. Vagina superficial, ventral, taking undulating course to genital atrium. Anterior portion of uterus forms on each side of midline three to four loops, anteriormost often extending anteriad to, or beyond, genital pore. Opcrculate eggs measure 61 to 73 by 37 to $45 \mu$ (av. 68 by $41 \mu$ ).

Cestodes from Fur Seal (Fig. 10)

The five available specimens were immature, measuring up to $158 \mathrm{~mm}$ in length. The scolices were similar to those of the cestodes from other hosts, mentioned above, and the secondary segmentation had the typical pattern. However, it cannot be established certainly that these cestodes represent the same species.

\section{Cestode from Domestic Mink}

The material consisted of a small portion of a strongly contracted strobila that was macroscopically indistinguishable from specimens of similar size from sea otters. The maximum width was $7.8 \mathrm{~mm}$; the segments were much wider than long, having a length/width ratio of about $1: 16$. According to findings in segments mounted in toto and in transverse sections, this cestode corresponds with the form from sea otters in the distribution of vitellaria, in arrangement and distribution of the testes, and in the size of the egg; it is concluded that this cestode is conspecific with that from the sea otter.

\section{Comparative Notes}

The slight morphological differences observed among these cestodes lead to my conclusion that the cestodes studied all represent the same species of Diplogonoporus. The range in the size of the strobilac is considered to be no greater than might be expected in cestodes of different ages occurring in hosts of different species. There is some indication also that the size of the strobila is inversely proportional to the massiveness of the infection.

Into one specific group should be placed, in my opinion, the cestodes studied by Wardle et al. (1947) ("type 3"), by Stunkard (1948) ("Species No. 3" 
and "Species No. 4"), and by Margolis (1956). The published descriptions and figures indicate that all are morphologically quite similar and therefore probably conspecific.

The uncertainty with which systematists have treated diplogonadic cestodes must stem, in large part, from the necessity to consider the original descriptions, few of which provide the criteria necessary to distinguish species. The complexity of the problem is such that a brief review of the taxonomic history is appropriate for the members of this group.

Bothriocephalus tetrapterus was described by von Siebold from Phoca sp., of unknown origin according to Braun (1894, p. 985), although the host was stated to be the harbor seal, $P$. vitulina Linnaeus, by Monticelli (1889) and Markowski (1952). Monticelli restudied von Siebold's original material in the British Museum and, in a $55 \mathrm{~mm}$ long cestode, observed the predominantly diplogonadic structure as well as the occasional presence of monogonadic segments. The species was tentatively assigned by Blanchard (1894) to the genus Krabbea, and soon thereafter it was transferred to Diplogonoporus by Ariola (1896). Lühe (1899) listed Krabbea as a synonym of Diplogonoporus and considered the status of D. tetrapterus to be uncertain. It was accepted as a valid species by Ariola (1900). Because of the irregularity in the arrangement of the genital organs, Baer (1932) concluded that the diplogonadic segments were anomalous and transferred the species to the genus Diphyllobothrium Cobbold, 1858. Wardle et al. (1947) established a new genus, Cordiocephalus, to which they proposed to assign this and certain other cestodes from pinnipeds; this arrangement was rejected by Stunkard (1948), who pointed out that Cordiocephalus is a synonym of Pyramicocephalus Monticelli, 1890.

Of the diphyllobothriid cestodes studied by Stunkard (1948), one diplogonadic form, "Species No. 3", from the fur seal was thought possibly to be referable to $D$. tetrapterus or to species described by Krabbe (1865), mentioned below. This opinion was expressed also by Markowski (1952), who published a complete redescription of the species, based on von Siebold's type material in the British Museum. Disagreeing with Baer's view that the arrangement of the genital organs is anomalous, Markowski reassigned the species to Diplogonoporus. Deliamure (1955) conditionally placed this species in the genus Diphyllobothrium, pending clarification of the significance of the variation in the arrangement of the genital organs. Cestodes from the Steller sea lion were identified as Diplogonoporus tetrapterus by Margolis (1956). Baer (1962), in accordance with his earlier conclusion, listed it under Diphyllobothrium in his synopsis of the species of cestodes recorded from Iceland.

Three species of essentially diplogonadic cestodes were described from various kinds of mammals by Krabbe (1865). Bothriocephalus dubius, briefly mentioned in an earlier paper (Krabbe 1864), was found in dogs and in a rat, Mus decumanus ( = Raltus norvegicus Berkenhout), in Iceland. Although the largest specimens, as much as $430 \mathrm{~mm}$ long, were immature, it is readily seen from Krabbe's figures (1865; Plate 6, Figs. 96-100) that this cestode possessed the typical, transverse subdivision of the segments and that the genital Anlagen were paired. B. variabilis was described from a hooded seal, Phoca cristata ( $=$ Cystophora cristata Erxleben), also from Iceland. The material 
consisted of 70 well-relaxed specimens measuring 50 to $1350 \mathrm{~mm}$ in length, with from one to three sets of genital organs per segment. Cestodes considered by Krabbe to be conspecific with the latter were obtained from a bearded seal, Phoca barbata ( = Erignathus barbatus Erxleben), in Iceland, and from a harbor seal in Scandinavian waters. The third species, B. fasciatus, was found in a ringed seal, Phoca hispida [ = Pusa hispida (Schreber)], at Godhavn, Denmark. The three specimens collected measured 280 to $800 \mathrm{~mm}$ long and had diplogonadic segments throughout; the segments were very short, having repeatedly subdivided transversely (Krabbe 1865, p. 379).

B. dubius has usually been considered to have been described too inadequately to permit its recognition, although Baer (1962) listed it as a synonym of Diphyllobothrium tetrapterum ( $=$ Diplogonoporus tetrapterus). Both $B$. variabilis and $B$. fasciatus were assigned to the genus Krabbea by Blanchard (1894). The latter was included in Diplogonoporus as a species of uncertain status by Lühe (1899), but he transferred B. variabilis to the genus Dibothriocephalus Lühe, 1899 ( = Diphyllobothrium) after examination of one of Krabbe's original specimens disclosed monogonadic segments throughout. Baer (1932) considered B. variabilis to be a synonym of Diphyllobothrium tetrapterum. D. fasciatus was one of the three species that he retained in the genus Diplogonoporus. D. variabilis and, presumably, D. fasciatus were treated in the same manner as D. tetrapterus by Wardle et al. (1947).

"Stunkard (1948) noted the similarity between his "Species No. 3" and the "type 3" of Wardle et al., and remarked that his species might be identical with one of the three previously described (D. tetrapterus, D. variabilis, or D. fasciatus). Markowski (1952) listed Stunkard's "Species No. 3" under D. tetrapterus. Cestodes identified as D. tetrapterus by Margolis (1956) were also considered to be very similar to "Species No. 3". Stunkard believed that his "Species No. 4" closely resembled D. fasciatus, but he remarked (p. 223) that no decision would be possible until the latter species had been described adequately. Since the original description of $D$. fasciatus does not permit certain recognition, it appears that this will never be accomplished. Markowski (1952) considered Stunkard's "Species No. 4" to be conspecific with $D$. fasciatus, basing this conclusion largely on a comparison of Stunkard's figures with those published by Krabbe (1874). As pointed out by Markowski, Krabbe's original description (1865, p. 479) contains little more than some details concerning the strobila and the size of the eggs. Markowski evidently attached no significance to the disparity between the two cestodes in the dimensions of the eggs, which measured 45 to $50 \mu$ long in Krabbe's specimens, but in Stunkard's material were 66 to $76 \mu$ long by 44 to $50 \mu$ in width. $D$. variabilis was listed as a synonym of $D$. tetrapterus by Markowski (1952), and $D$. fasciatus was retained as a valid species, a conclusion also expressed by Deliamure (1955), although the three species were transferred by him to the genus Diphyllobothrium.

D. septentrionalis Kholodkovskii, 1915, from Phoca sp. from the Arctic Ocean (Siberia), not considered by Baer (1932) in his review of the members of the genus Diplogonoporus, was listed by Markowski (1952) as a synonym of $D$. tetrapterus. It was regarded as a valid species by Deliamure (1955) and by Belopol'skaia (1960). D. mutabilis Belopol'skaia, 1960 was described from 
material obtained from harbor seals in Whale Bay, northern Sea of Japan. These latter cestodes exhibited unusual variation in the arrangement of the genital organs, some segments possessing up to five sets. Of the seven strobilae studied, the predominating number of genital complexes per segment was three in five strobilae, four in one, and two in one; however, there was little uniformity in any individual cestode (see Bclopol'skaia 1960, Fig. 1). The anatomical details are not described sufficiently to permit a clear understanding of the relationships of some structures. Although it was reported that the cirrus sac, vagina, and uterus open separately in D. mutabilis, this cestode is possibly identical with one of the species previously described from seals.

The cestodes referable to the genus Diplogonoporus considered in section II above fall into two groups on the basis of the dimensions of the eggs. One group possesses comparatively small eggs, according to the published descriptions: D. tetrapterus [Markowski's (1952) findings in von Siebold's type material], 43 to 46 by 33 to $40 \mu ; D$. variabilis, $40 \mu$ long (from hooded seal), 45 to $50 \mu$ long (from bearded seal), and 45 to $50 \mu$ long (from harbor seal); D. fasciatus, 45 to $50 \mu$ long; D. septentrionalis, 45 by $15 \mu ; D$. mutabilis, 47 to 55 by 29 to $34 \mu$. The cestodes considered in the present paper under the name $D$. tetrapterus together with certain others reported in the literature [Stunkard's "Species No. 3", 68 to 78 by 40 to $48 \mu$; "Species No. 4", 66 to 76 by 44 to $50 \mu$; and D. tetrapterus of Margolis (1956), 63 to 71 by 36 to $45 \mu$ ] make up a group having relatively large eggs. In the absence of other morphological characteristics that would serve to distinguish the members of the two groups, the significance, if any, of the differences in dimensions of the eggs is not clear. Two possibilities are that there are at least two species of these smaller cestodes, or that there is a single species in which the dimensions of the eggs are rather widely variable. Since intraspecific variation in size of eggs is often noted in diphyllobothriid cestodes, the differences observed here probably represent only normal variation. However, intergradation between the two groups is not evident. Until information to the contrary becomes available, it seems appropriate to apply the oldest available name, D. tetrapterus (von Siebold, 1848), to the species of smaller cestode discussed in this study.

\section{Discussion}

Although the life cycle is not known for any species of Diplogonoporus, the plerocercoid stage, from all indications, can be expected to occur in fishes. $D$. balaenopterae seems to have an extensive distribution, being harbored by whales in the Antarctic (Markowski 1955) as well as in northern waters. The finding of cestodes of this species in man in Japan and in a dog in Alaska demonstrates the presence of the infective larvae in northern regions. $D$. balaenopterae has been recorded from baleen whales of four species, namely, blue whale, Balaenoptera musculus Linnaeus; fin whale, B. physalus (Linnaeus); sei whale, $B$. borealis Lesson; and humpback whale, Megaptera novaeangliae (Borowski), all of which are known to feed on fishes in addition to krill. Fishes have been taken from the stomach of blue whales in the Antarctic (Tomilin 1957, p. 113). According to the same source, fishes of the following 
species have been identified from the stomach of fin whales in northern waters: Clupea harengus, Mallotus villosus, Ammodytes personatus, Boreogadus saida, Eleginus gracilis, Theragra halcogramma, Gadus morrhua, Pleurogrammus monoptergius, Sebastodes glaucus, Osmerus eperlanus, Oncorhynchus keta, Sardinella melanostica, Engraulis japonicus, Cololabis saira, and Podonema longipes. Data on fishes eaten by the sei whale have been published by Rice (1963), who examined 77 of these mammals from waters off the Pacific Northwest, with the following findings: Engraulis mordax was present in 29 animals $(37 \%)$; Cololabis saira in $8(10 \%)$; and Sardinops sagax in one stomach. From humpback whales taken in the Bering Strait and in the Chukchi Sea during August-September, Tomilin listed the following species: Mallotus villosus, Clupea harengus, and Ammodytes personatus. Rice examined 149 of these whales from waters off the Pacific Northwest and found Engraulis mordax in 98 stomachs $(65 \%)$. Diplogonoporus $\mathrm{sp}$. has been recorded also from the sperm whale, Physeter catadon Linnaeus, which, according to Tomilin, feeds to some extent on fishes.

In man, the highest rate of infection is to be expected, as is, in fact, the case in Japan, in coastal populations regularly utilizing smaller marine fishes as food. Diplogonoporus sp., presumably $D$. balaenopterae in all cases, has been reported from man in Japan on 25 occasions during the period 1894-1961 (Morishita 1962). D. tetrapterus might also be expected to occur in man. Since the eggs alone are not diagnostic, identification of these cestodes depending on availability of the strobila for study, infections in man may be more frequent than the number of records indicates.

Cestodes of the genus Diplogonoporus have not been recorded from man in Alaska, where, in some coastal regions (e.g., Yukon-Kuskokwim lowlands), rates of infection with diphyllobothriid cestodes, mainly Diphyllobothrium spp., attain $30 \%$ or more. Marine fishes, including some of those listed above from the stomachs of whales, are heavily utilized by the aboriginal inhabitants of the region. That these fishes comprise a source of plerocercoids is demonstrated by the finding of at least two species of diphyllobothriid cestodes that occur commonly in seals in both man and dog (Rausch, unpublished). Much material has been obtained from dogs by means of autopsy, so that diplogonadic cestodes, if present, would scarcely be overlooked. The fishes harboring the larvae of Diplogonoporus spp. probably exist under ecological conditions differing from those prevailing along the coast of western Alaska, a region characterized by shallow, rather turbid waters of low salinity over a muddy bottom.

Of the seven species of pinnipeds from which $D$. tetrapterus has been reported, five (fur seal, Steller sea lion, harbor seal, ringed seal, and bearded seal) frequent Alaskan waters. In this region the cestode has been found in both the fur seal and the sea lion but never in any individuals of the large series of phocids that has been examined. Little is known about the occurrence of $D$. tetrapterus in the fur seal, but this species is apparently a rather common parasite of the Steller sea lion. D. tetrapterus has been found also in the sea otter, a mustelid, in Alaska on several occasions and may occur in this host in the Commander Islands as well. Diplogonoporus sp. has been reported from that area by Barabash-Nikiforov (1947, see above) and by Afanas'ev (1941). 
The sea otter inhabits relatively shallow waters of the littoral zone, where infections by helminths, including $D$. tetrapterus, must be acquired. Sea lions, found in similar situations during much of the year, probably feed on some of the same species of fishes as do sea otters. The mink reported above as a host of D. tetrapterus had been kept on a fur farm at Petersburg, in southeastern Alaska, where, according to Dr. J. B. Loftus who collected the cestode, it had been fed ". . . only on fish originating in salt water." These fishes, caught locally, had probably been obtained in coastal waters. The occurrence of $D$. tetrapterus in sea otters strongly suggests that the plerocercoid of this cestode may be found in hexagrammids and other fishes that inhabit rocky shores and kelp beds such as those typical of the Aleutian Island region. Similar conditions exist in other northern waters, as around the Commander and Kurile Islands. Because of their migratory habits, sea lions might, on the other hand, also become exposed to infection away from such coastal areas.

The morphological variability of the smaller cestode designated here as $D$. tetrapterus has led some workers to assign it to the genus Diphyllobothrium. Baer's opinion that such cestodes should be regarded as anomalous specimens belonging to the latter genus has been mentioned; a similar attitude was expressed more recently by Deliamure (1955, p. 188) as follows: "As a result of an analysis of all the relevant literary sources we have established that the overwhelming majority of these species are not representatives of the genus Diplogonoporus. It appears that the authors related to this grenus such forms of diphyllobothriids in which the entire strobila was not diplogonadic, but only certain of its segments. However, abnormal duplication of the genital system in certain parts of the segments of the strobila is not an indication of the genus Diplogonoporus. To this genus should be related only those species in which the diplogonadness [diplogonadnost'] is inherent in all the segments of the strobila and is a character continuously linked with a corresponding increase in the width of the segment. Only one species answers these demands, $D$. balaenopterae, whereas all the remaining are either inadequately described and doubtful representatives of this genus or they should be related to the genus Diphyllobothrium." After a detailed study of von Siebold's type material, Markowshi (1952) retained D. tetrapterus in the genus Diplogonoporus, with no uncertainty about the appropriateness of this decision. He stated (p. 202) that the genital organs were arranged in both single and double sets, although he gave no data on the relative proportions of the two types. His Fig. 36 exhibits a variation in the arrangement of the genital organs identical with that described by Stunkard (1948) and by Margolis (1956), and that observed in some of my material. Although variance from strobila to strobila may have been noted by Markowski, he did not state that in number of genital organs, the strongest element among the segments was other than duality. That diplogonadic segments predominated in Stunkard's material is clearly evident from his detailed descriptions, and this predominance was the case in all of the specimens that I studied. For example, in randomly selected fragments of strobilae, comprising a total of 553 segments, from the sea otter obtained at Montague Island in 1962, discrete segments having one, two, or three sets of genital organs numbered 8,374 , and 5 , respectively. There were, in addition, 14 segments in which the process of transverse subdivision had been incomplete, resulting in the presence of two sets of genital organs in the anterior portion 
but only one in the partially separated posterior half. Two cestodes, from the sea lion collected on St. Lawrence Island, had two, three, or four sets in 93, 0, and 2 segments, and in 43, 3, and 2 segments, respectively. In part of a strobila from a sea otter taken at Amchitka Island in 1956, one, two, or three sets of genital organs were observed in 35,46 , and 6 segments, respectively.

The generic position of $D$. balaenopterae has evidently not been questioned, partly because of its distinctive size and partly, perhaps, because it does not appear to be as variable morphologically as is D. tetrapterus. The morphological anomalies most frequently observed in $D$. balaenopterae are an incomplete subdivision of the segments and the presence of supernumerary sets of genital organs. The former often involves extension of the line of segmental subdivision mediad to the vicinity of the uterus on only one side, resulting in two sets of genital organs in the anterior portion and one in the posterior, as described above for D. tetrapterus. The line of separation may extend mediad from both sides, reaching the vicinity of the uterine loops but not affecting the diplogonadic condition. When only a single set of genital organs is present in discrete segments in $D$. balaenopterae, characteristically it occupies a normal position rather than being situated at the midline, as often is observed in D. tetrapterus. Any supernumerary sets of genital organs, usually rudimentary but sometimes functional, will lie in the space between the normal complexes. These may number from one to four, most often seen as rudiments of uteri. When functional, the uteri usually are not as large as those in normal position but contain fully developed eggs. However, all such supernumerary complexes may be potentially functional. The hexagonadic cestode Hexagonoporus physeteris Gubanov, 1952 (see Deliamure 1955, p. 194 and Fig. 113; original description not seen), from a sperm whale, may represent a specimen of $D$. balaenopterae in which the supernumerary sets of genital organs had attained full development and were uniform in numbers in the series of segments obtained (description based on two fragments, 996 and $323 \mathrm{~mm}$ long). One of the strobilae described by Belopol'skaia (1960), under the name D. mutabilis, is evidently comparable, although there is less uniformity in the number of sets of genital organs (see Belopol'skaia, Fig. 1,b).

My observations suggest that anomalies in number of the genital complexes of Diplogonoporus species are related to the process of secondary subdivision of segments. The failure of segments to subdivide may result in four sets of genital organs arranged in the normal position, whereas when subdivision is partial, only three sets may be present. The tendency for two sets of genital organs to coalesce, typically preceding series of monogonadic segments as described by Stunkard (1948, Fig. 14) and by Markowski (1952, Fig. 36), and as noted in my material, evidently involves another mechanism. The cestodes of this genus seem to exhibit an inherent lack of stability in the developmental processes leading to the formation of genital complexes. This quality, however, probably has positive adaptive significance.

An attempt has been made in the foregoing discussion to point out the predominance of diplogonadic segments in cestodes of the genus Diplogonoporus, and that the variation noted in the number of genital organs does not justify the conclusion that the entire organism is anomalous. Further evidence against the latter concept can be presented, for if the diplogonadic cestodes 


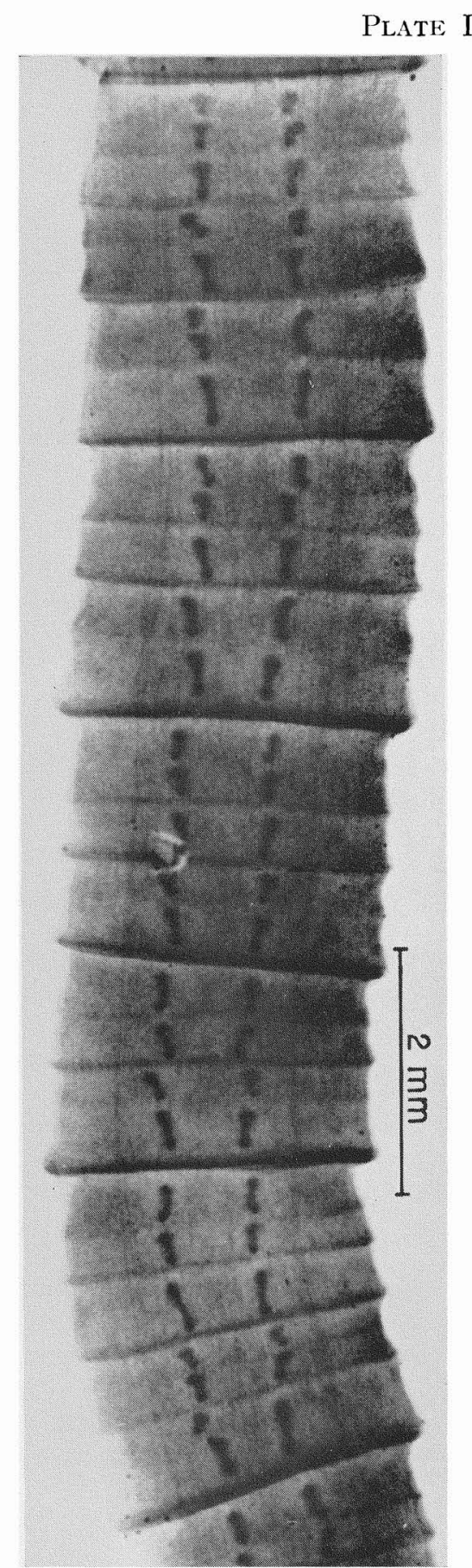

Fig. 11. Photograph of posterior portion of immature strobila of D. tetrapterus from Steller sea lion, showing subdivided prinary segments.

Rausch-Can. J. Zool. 
were other than normal, it would seem highly improbable that infections comprised exclusively of such individuals would be observed repeatedly in pinnipeds, particularly in the Steller sea lion. Neither have the monogonadic (i.e., "normal") representatives of the species to which the allegedly anomalous forms belong been identified. I have never observed diplogonadic segments in the species of Diphyllobothrium [e.g., D. lanceolatum (Krabbe, 1865);D. cordatum (Leuckart, 1863)] that occur commonly in phocids in Alaskan waters. There is some variation in the number of sets of genital organs in species of Diphyllobothrium whose larval development takes place in freshwater organisms, but the supernumerary sets in these cestodes are nearly always in tandem arrangement, found in abnormally elongate segments. The symmetrical, transverse arrangement typical of Diplogonoporus is not seen. Neither was it observed by Grohmann (1907) in his study of variation in the segments of diphyllobothriid cestodes.

The multiplication of segments by means of transverse subdivision is a method of growth unique in cestodes of the genus Diplogonoporus. This process was first described by Krabbe (1865) and has been recognized by others (Ijima and Kurimoto 1894; Kurimoto 1900; Stunkard 1948; Markowski 1952; Margolis 1956). In my material, sequential changes in the segments were particularly clearly seen in the well-relaxed specimen of $D$. balaenopterae from a dog. Secondary and even tertiary subdivision had taken place in the segments immediately following the scolex (Fig. 1), and continuation of the process had resulted in the formation in the posterior part of the strobila of as many as 8 to 10 reproductively functional segments from each primary segment derived from the neck region (the original margins of the primary segments are more strongly defined than those of the segments produced by transverse division, so that the identity of the separate units is preserved). A similar process takes place in $D$. tetrapterus. In an immature specimen from a sea lion, for example, 490 discrete segments were present in the $255 \mathrm{~mm}$ long strobila, having been derived from 215 primary segments. The younger proglottids, comprising more than half of the strobila $(150 \mathrm{~mm})$, had subdivided but once; thereafter the process had further progressed, resulting in the production of as many as nine segments from a single primary segment near the posterior end of the strobila (Fig. 11). Since some secondary or tertiary units fail to subdivide further, the groups finally produced are not always in multiples of two.

Strobilization in cestodes, as Stunkard (1962, p. 26) pointed out, is a process of asexual reproduction preceding sexual reproduction within the proglottids. In cestodes of the genus Diplogonoporus, strobilization is followed by a second asexual generation of segments produced by means of fission of the primary units. Deliamure $(1955$, p. 189) has suggested that the doubling of the genital organs in Diplogonoporus results in a greater number of eggs and represents an adaptation that significantly increases the probability of reproductive success. Asexual reproduction by transverse subdivision represents a further adaptation that would appear to have the effect of raising the production of eggs by as much as 10 times over the expected if only the original diplogonadic primary segments were involved. Such reproduction through subdivision seems also to bring about a diminution in the number of primary segments 
generated within a given period of time. The significance of the formation of fewer primary segments by strobilization from the neck is not clear, but possibly such growth is a mechanism whereby the cestodes are able to survive longer in their long-lived hosts.

The cestodes of the genus Diplogonoporus are highly specialized and appear to be even more distantly removed from their hypothetical free-living ancestor than are, for example, Diphyllobothrium species. These diplogonadic tapeworms occur in mammals (cetaceans and pinnipeds) of comparatively ancient origin (see Simpson 1945), and the adaptations that serve to enhance the probability of infection of the first intermediate host in the marine habitat seem strongly to suggest a parasite-host association of great age.

\section{Acknowledgments}

This study was based largely on specimens collected by Karl W. Kenyon and Dale W. Rice, Marine Mammal Biological Laboratory, United States Fish and Wildlife Service, Seattle, and by James W. Brooks and Kenneth A. Neiland, Alaska Department of Fish and Game, Juneau and Anchorage, respectively. Dr. Allen McIntosh, Animal Disease and Parasite Research Division, United States Department of Agriculture, Beltsville, kindly loaned specimens from the Collections of the United States National Museum. Some of the cestodes from Alaskan mammals were collected by Everett L. Schiller, Johns Hopkins University, Baltimore, and by Douglas K. Hilliard and Francis H. Fay (who read the manuscript as well), Arctic Health Research Center. Technical assistance was provided by Mrs. R. V. Rausch, who also prepared the figures, and by Kenneth L. Austerman. The assistance of these persons is gratefully acknowledged.

\section{References}

AfANAS'Ev, V. P. 1941. Parazitofanna promyslovykh mlekopitaiushchikh Komandorskilih Ostrovov. Uch. Zap. Letningr. Gros. Univ. Ser. Biol. Nauk, 18, 93-117.

Ariola, V. 1896. Soprat alcuni Dibotrii nuovi o poco noti e sulla classificazione del gen. Bothriocephalus. Boll. Musei Zool. Anat. Comp. Univ. Genova, No. 52, vol. 2.

___ 1900. Revisione della famiglia Bothriocephalidac s. str. Arch. Parasitol. 3, 369-484.

BaEr, J. G. 1932. Contribution à l'étude des cestodes de cétacés. Rev. Suisse Zool. 39, 195 228. 1962. Cestoda. In Zoology of Iceland. Vol. 2, P't. 12. Munksgaard, Conenhagen.

Barabash-Nikiforov, I. I. 1947. The sea otter. National Science foundation translation, Jerusalem, 1962.

Beropol'skara, M. M. 1960. Gel'mintofauna larga (Phoca vitulina largha Pall.). Vestn. Leningr. Univ. Ser. Biol. 15(3), 113-121.

Blanchard, R. 1894. Notices sur les parasites de l'homme. IV. Sur le Krabbea grandis, et remarques sur la classification des Bothriocéphalinés. Compt. Rend. Soc. Biol. Paris, 46, 699-702.

Braun, M. 1894. Vermes. In Bronn's Klassen und Ordnungen des Thier-Reichs. Abt. I.b. Cestodes. 4, 927-1731.

Deliamure, S. L. 1955. Gel'nintofauna morskikh mlekopitaiushchikh v svete ikh ekologii i filogenii. Akad. Nauk SSSR, Moscow.

Grommann, W. 1907. Die Abnormalitäten in den Proglottiden der Cestoden, insbesondere der Bothriocephaliden. Ber. Obcrhess. Ges. Natur-Heilk. Giessn, Naturw. Abt. N. F. $1(1904-1906), 1-42$.

Ijima, I. and Kurimoto, T. 1894. On a new human tape-worm (Bothriocephalus sp.). J. Coll. Sci. Imp. Univ. Japan, 6, 371-385.

KRABBE, H. 1864. Undersögclser angaaende Forekomsten af Indvoldsorme i Hundens og Kattens Tarmkanal i Danmark og paa Island. Tidsskr. Vet. Kjøbenhavn, 12, 175195.

186.5. Helminthologiske Undersögelser i Danmark og paa Island, med saerligt IIensyn til Blaereormlidelserne paa Island. Kgl. Danske Videnskab. Selskab. Skrifter Naturvidenskab. Math. Afdel. 7, 347-408. 
1874. Diplocotyle Olrikii, en uleddet Baendelorm af bothriocephalernes Gruppe. Videnskab. Medd. Naturhist. Foren. Kjöbenhavn, 6, 22-25.

Kurimoto, T. 1900. Diplogonoporus grandis (R. Blanchard), Beschreibung einer zum ersten Male im menschlichen Darm gefundenen Art Bothriocephalus. Zeitschr. Klin. Med. 40, $1-16$.

Lönnberg, E. 1892. Anatomische Studien über skandinavische Cestoden. II. Zwei Parasiten aus Walfischen und zwei aus Lamna cornubica. Kgl. Svenska Vetenskapsakad. Handl. 24, 4-28.

LüHe, M. 1899. Zur Anatomie und Systematik der Bothriocephaliden. Verhandl. Deut. Zool. Ges. 9, 30-55.

Margolis, I. 1956. Parasitic helminths and arthropods from pinnipedia of the Canadian Pacific coast. J. Fisheries Res. Board Can. 13, 489-505.

Markowski, S. 1952. The cestodes of pinnipeds in the Arctic and other regions. J. Helminthol. 26, 171-214.

1955. Cestodes of whales and dolphins from the Discovery Collections. Discovery Repts. 27, 377-395.

Monticeldi, S. 1889. Notes on some entozoa in the Collection of the British Museum. Proc. Zool. Soc. London, 21-22, 321-325.

Morishita, K. 1962. [Studies on Diplogonoporus.] (In Japanese.) Progr. Parasitol. Japan, 2, $1-24$.

RICE, D. W. 1963. Progress report on biological studies of the larger Cetacea in the waters off California. Norsk Hvalfangst-'Tidende, No. 7, 181-187.

Simpson, G. G. 1945. The principles of classification and a classification of mammals. Bull. Am. Museum Nat. Hist. 85

Stuxkart, H. W. 1948. Pseudophyllidean cestodes from Alaskan pinnipeds. J. Parasitol. $34,211-228$.

- 1962. The organization, ontogeny, and orientation of the Cestoda. Quart. Rev. Biol. $37,23-34$.

Tomim, A. G. 1957. Zveri SSSR i prilezhashchikh stran. IX. Kitoobraznye. Akad. Nauk SSSR, Moscow.

Warde, R. A., Mcleod, J. A., and Strwart, I. E. 1947. Lühe's "Diphyllobothrium" (Cestoda). J. Parasitol. 33, 319-330.

Yamaguti, S. 1942. Studies on the helminth fauna of Japan. Pt. 42. Cestodes of mammals II. Kyoto Imp. Univ. 